\title{
FAREWELL FOR ADRIAN
}

Speech given via video by

Professor Christine Parker, Melbourne Law School, The University of Melbourne.

christine.parker@unimelb.edu.au

Hi Adrian! Hi everybody! Sorry I can't be there. I didn't want to miss out on the opportunity to pass on my best wishes to Adrian and celebrate what he's been doing, and particularly in legal ethics. So I've made this video with the help of my husband, Simon Kerr.

I thought I'd tell you a little bit about what Adrian and I have done together and that's also a good advertisement for the third edition of our book Inside Lawyers' Ethics [shows book to audience - see photo]. ${ }^{1}$

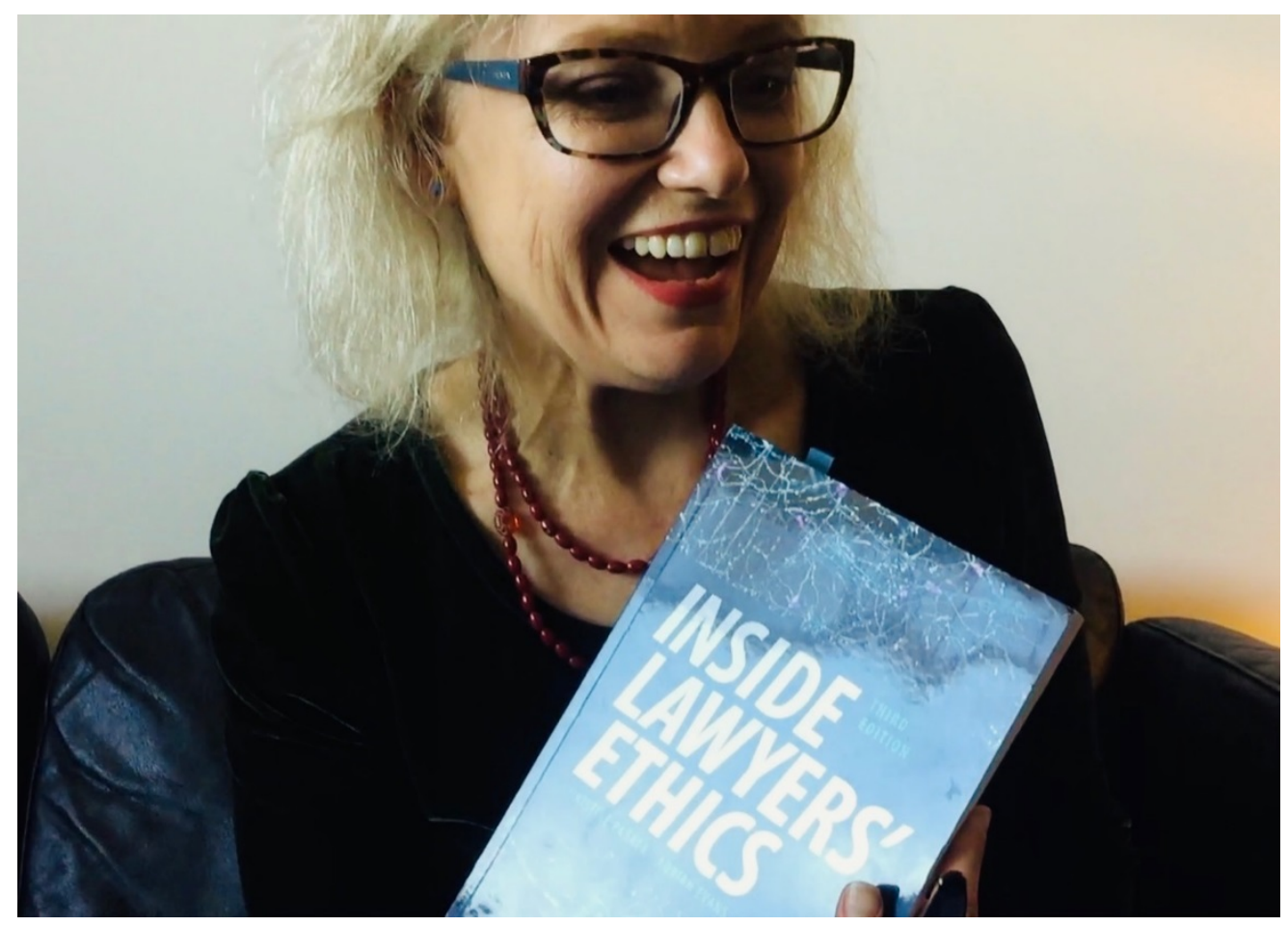


I first met Adrian when I was doing my PhD on lawyers' ethics and the regulation of lawyers, and I had to interview all of the movers and shakers who were advocating for reform to the legal profession at the time back in 1995. Everyone said, 'Oh you must talk to Adrian Evans'. So I went to Melbourne; I talked to Adrian Evans. I can't remember what he said(!) but it obviously made an absolutely huge impression on me... About seven years later, I moved to University of Melbourne and I wanted a friend and a colleague to write a book with, so I emailed Adrian and said, 'Could we have lunch? I've got something I want to discuss with you'. He came and had lunch and I asked him to co-author what became Inside Lawyers' Ethics with me. I'd got the agreement of Cambridge University Press to do something a bit different to the normal law type text book, something a lot more practical and full of case studies, but still very scholarly. I knew Adrian was the perfect person to help me with that because I didn't have as much practical experience as he had.

So, I think what we did in this book really picked up a lot of the things Adrian had been doing and continues to do in contributing to lawyers' ethics and justice in the legal profession. He'd established and worked with the Latrobe University law clinic and then Springvale Monash Legal Service. He'd been helping people who had bad experiences with the legal system and also bad experiences with lawyers. $\mathrm{He}^{\prime} \mathrm{d}$ been teaching legal ethics. He'd been writing a regular column for the Law Institute Journal on legal ethics, and just generally advocating for justice in the legal profession. This book picked all those things up. But that doesn't really tell you the main thing which 
is that Adrian has a unique combination of passion for justice and for doing the right thing, and compassion and care for people in real situations.

I think the best illustration of that is the number of times I've met somebody who was a student of Adrian's at the Springvale Monash Legal Service and they've remembered both the vision that he gave them but also the pastoral care that he gave them. I hope that that's reflected in the way that we write the book, and in the way that we taught legal ethics together at Monash and I continue to teach it at Melbourne University.

Now there's some things that we tried to do together that didn't work so well, like for example I think we tried about three times to get a research grant to look at ethics in large law firms, and that didn't work so well. We never got it -- although we did publish a special issue of Legal Ethics on lawyers' ethics in large law firms and a hardhitting opinion piece on the topic. ${ }^{2}$

And also, as many of you know, Adrian has had a rather unpopular passion for years on the issue of how the interest on lawyers' trust accounts is used. I used to talk to people and mention Adrian and they'd roll their eyes when we got to the interest on lawyers' trust accounts because Adrian has a very strong sense of justice that that interest ethically belongs to the clients. ${ }^{3}$ Also, as a matter of justice, Adrian believes that government should be responsible for funding legal aid as a citizenship right, not as a matter of charity from lawyers. And I think he's right, he's convinced me of that over the years. 
I know that Kate Seear has organised this event as a Festschrift that usually occurs when somebody retires but Adrian doesn't like the ' $R$ ' word - "retirement" - so that's not to be mentioned anywhere near Adrian. In fact really what he is doing is creating more time so that he can go and save the world from ecological destruction and fight for climate justice. I do remember him coming back from an International Bar Association meeting where Mary Robinson had spoken about the urgent need for all of us to do everything that we can do in the fight against climate change and she particularly encouraged lawyers to do something. In the latest edition of Inside Lawyers' Ethics we do include some discussion of those issues as part of the broader ethics for lawyers.

So, to finish off, I, and my lovely husband Simon Kerr, who is about to appear in this video, thought that we would sing a little song to inspire Adrian and all of you in the fight for climate justice (see photo).

Let's have one last cheer for coal It's done so much for humanity But now it's clear it's simply mad To burn more coal for energy

For reasons that are clear and now It's time to say farewell So cheerio, our old friend coal Cheerio coal, cheerio

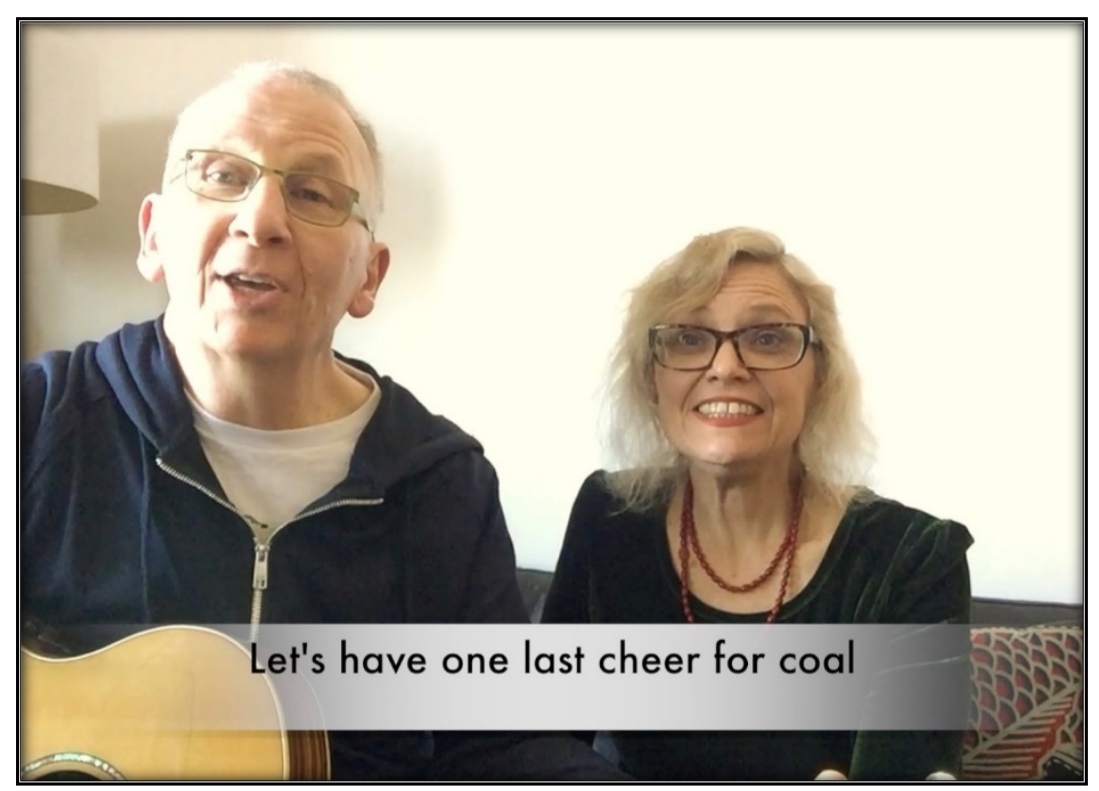


Well let's have one last cheer for Adrian

He's done so much for humanity

Now it's clear it's simply mad

To do administration for eternity

For reasons that are clear and now

Well he must save the world

So cheerio, Adrian, cheerio ${ }^{4}$

\footnotetext{
${ }^{1}$ Christine Parker and Adrian Evans, Inside lawyers' Ethics, $3^{\text {rd }}$ edition, 2018, Cambridge University press, Melbourne.

${ }^{2}$ Christine Parker, Suzanne Le Mire and Adrian Evans (guest editors), special issue of Legal Ethics, 11(2), 2008 on "Ethical Climate in Corporate and Commercial Law Firms"; Adrian Evans, Linda Haller and Christine Parker, "McCabe case a lesson for all" The Sunday Age (Melbourne), 5 November 2006, 21. See also Christine parker, Adrian Evans, Linda Haller, Suzanne Le Mire and Reid Mortensen, "The ethical infrastructure of legal practice in larger law firms: values, policy and behaviour" University of New South Wales Law Journal, 31(1), 2008, 158188.

${ }^{3}$ See Adrian Evans, "Professional ethics North and South: Interest on clients' trust funds and lawyer fraud. An opportunity to redeem professionalism." International Journal of the Legal Profession 3.3 (1996): 281-300.

${ }^{4}$ Lyrics written by Simon Kerr, "One last cheer for coal", 2018. For more about this work, see www.musicforawarmingworld.org
} 